\title{
Measurement of the rate of flow of dry matter in digesta passing through the duodenum of sheep
}

\author{
By J. D. OLDHAM* aNd J. R, LING† \\ University of Nottingham, School of Agriculture, Sutton Bonington, \\ Loughborough, Leics. $L E_{12}{ }_{5} R D$
}

(Received 5 December 1975 - Accepted 20 August 1976)

\begin{abstract}
I. A total of seven sheep fitted with re-entrant cannulas in the proximal duodenum were used in three experiments to measure the passage of dry matter (DM) in duodenal digesta.

2. Fifty-three $24 \mathrm{~h}$ measurements and ten $48 \mathrm{~h}$ measurements of DM flow were made in Expt I. Coefficient of variation (CV) of these measurements was $22 \cdot 1 \%$ which was similar to variability reported for chromic oxide 'corrected' flows and for an estimate of day-to-day variation. DM flow on day I was $103.2 \%(\mathrm{sE}=8.94)$ of fow on day 2 in $48 \mathrm{~h}$ measurements.

3. In two $3 \times 3$ Latin-square design experiments, duodenal $\mathrm{DM}$ flow was measured continuously over $72 \mathrm{~h}$ and on days $\mathrm{I}, 2$ and 3 DM flow was $100.4,102.6$ and $96.9 \%(\mathrm{SE}=5.82$ ) of mean flow (Expt 2) and $95.8,101 \cdot 2$ and $103.0 \%(\mathrm{SE}=6.70)$ of mean flow (Expt 3$)$ respectively.

4. It was concluded that no depression in duodenal DM flow occurred during the first $24 \mathrm{~h}$ of collection in these experiments and that the variability of repeated $24 \mathrm{~h}$ measurements of flow was within day-to-day variation.
\end{abstract}

Re-entrant cannulas have been placed at specific points in the digestive tract of ruminants to allow measurement of the rate of flow of digesta past these points. Most reports have described flow measurements of $24 \mathrm{~h}$ duration (for example Bruce, Goodall, Kay, Phillipson \& Vowles, 1966; MacRae \& Armstrong, 1969; Nicholson \& Sutton, r969; Thomson, Beever, Coelho da Silva \& Armstrong, 1972; Thompson, I973; Ulyatt \& MacRae, 1974) but there have been a few studies over longer collection periods (Goodall \& Kay, I965; van 't Klooster, Rogers \& Sharma, I969; Thompson \& Lamming, r972; van 't Klooster, Kemp, Geurinck \& Rogers, 1972). The length of the collection period has been limited by the labour-intensive nature of manual or semi-automated collection procedures. Fully automated measuring and sampling equipment has been described (Axford, Evans \& Offer, 1971; Corse, 1974) although only short reports of studies with these machines have appeared in the literature (Offer, Axford \& Evans, 1972; Offer, Evans \& Axford, 1972; Tas, Offer, Evans \& Axford, 1974; Sutton, Youssef \& Oldham, 1976).

Because collection periods have been mostly short $(24 \mathrm{~h})$ many workers have used an indigestible reference substance to allow correction for inevitable day-to-day variations in measured digesta flow. The most commonly used marker in ruminant digestion studies has been chromic oxide, despite the inadequacies of this material as a marker (Drennan, Holmes \& Garrett, 1970; Faichney, 1972; MacRae, 1974).

* Present address: Department of Feeding and Metabolism, National Institute for Research in Dairying, Shinfield, Reading RG2 9AT, Berkshire.

+ Present address: Department of Biochemistry and Agricultural Biochemistry, University College of Wales, Aberystwyth SY23 2AX. 
Furthermore, it has been found by several groups that, for continuous digesta collections of $24 \mathrm{~h}, \mathrm{Cr}_{2} \mathrm{O}_{3}$ recovery in digesta averaged only about $85 \%$ (Bruce et al. 1966; Topps, Kay \& Goodall, 1968; MacRae \& Armstrong, 1969; Nicholson \& Sutton, I969; MacRae, Ulyatt, Pearce \& Hendtlass, 1972). It was considered that this reflected a depression in digesta flow, perhaps as a result of the stress of experimental procedure. Support for this was given by Goodall \& Kay ( 1965 ) in $72 \mathrm{~h}$ measurements of ileal digesta flow. They suggested that flow in the first $24 \mathrm{~h}$ of collection was less than the average flow for $3 \mathrm{~d}$, but that this was compensated by an increased flow on the second day. No markers were used in that study, but van 't Klooster et al. (1969) measured duodenal digesta flow and daily marker $\left(\mathrm{Cr}_{2} \mathrm{O}_{3}\right)$ recoveries over 72 or $\mathrm{I} 20 \mathrm{~h}$ periods and confirmed that $\mathrm{Cr}_{2} \mathrm{O}_{3}$ recovery was reduced in the first $24 \mathrm{~h}$ of collection, although over-all recovery was invariably close to $100 \%$.

In contrast, Thompson \& Lamming (1972) could find no difference between days in $72 \mathrm{~h}$ continuous duodenal digesta collections for either dry matter (DM) or digesta flow. This was used by them to justify the measurement of digesta flow over $24 \mathrm{~h}$ without marker correction although no marker was used in the $72 \mathrm{~h}$ study.

We have adopted the experimental procedure of Thompson \& Lamming (1972), and have measured digesta flow over 24,48 and $72 \mathrm{~h}$ in sheep fed on a variety of diets with the purpose of studying the effect of the duration of measurements on measured DM flow and to obtain an estimate of the reliability of repeated $24 \mathrm{~h}$ determinations of flow.

We found no difference in DM flow between the first and subsequent $24 \mathrm{~h}$ periods of a duodenal digesta collection and also concluded that the variability of repeated $24 \mathrm{~h}$ measurements of flow was within day-to-day variation.

\section{METHODS}

\section{Animals and feeding}

Seven crossbred wethers were used in these experiments. Each was fitted with a re-entrant cannula in the proximal duodenum by the technique used by Thompson \& Lamming (1972). The sheep in Expts I and 2 were fed once daily at I I.00 hours and those in Expt 3 were fed hourly from a continuous belt feeder. All sheep had continuous access to water. Between digesta collection periods the sheep were kept in individual pens with wire mesh floors. The day before collection they were moved to standard metabolism crates and remained there until all collections for a particular dietary treatment had been completed.

\section{Diets}

Diets $1-9$ (Table 1 ) were used in Expt 1 , diets 10-12 in Expt 2 and diets $13-16$ in Expt 3 .

Change-over from one diet to another was completed in $4 \mathrm{~d}$ and at least a further Io $\mathrm{d}$ on full ration was allowed before any duodenal collections were made.

Diets $3,6,9$ and $\mathrm{I} 2$ were fed as loose mixes since they had a high molasses content and could not be pelleted. All other diets were pelleted. 
Vol. 37

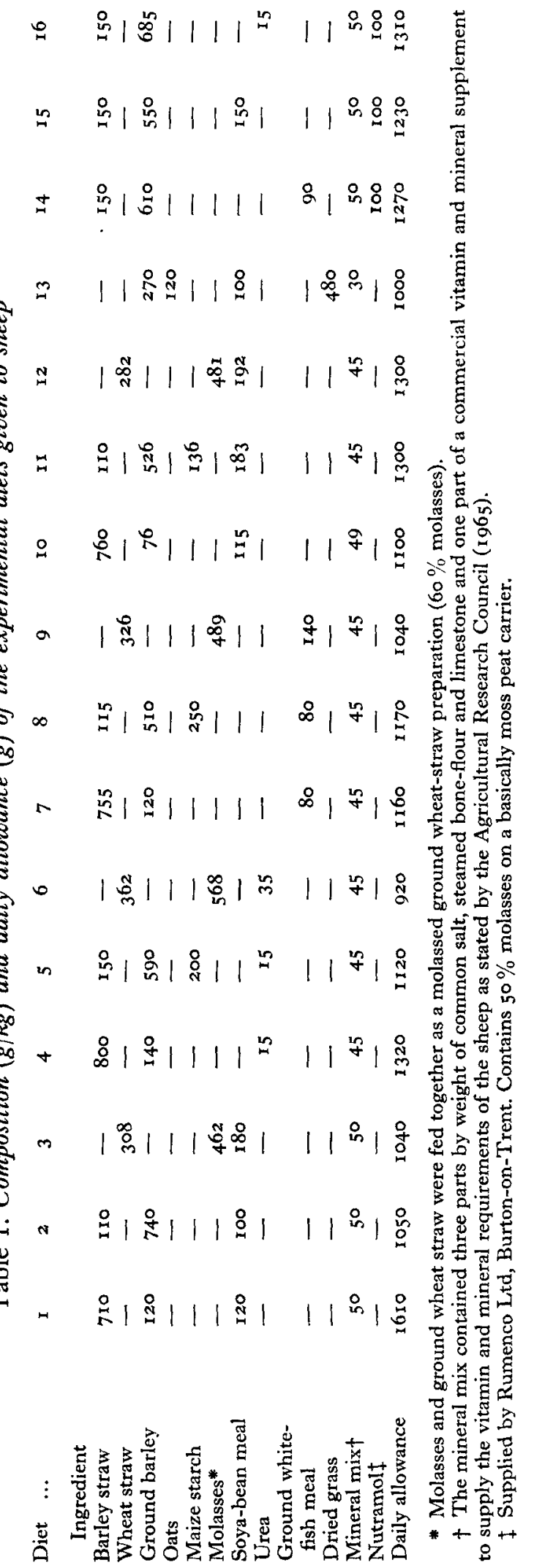




\section{Duodenal digesta collections}

Sheep $\mathrm{H}, \mathrm{M}$ and $\mathrm{P}$ were acclimatized to the experimental routine by making two collections of $24 \mathrm{~h}$ duration before the start of Expt $\mathrm{r}$. They were given a diet of dried, pelleted grass at that time. Expt I began immediately thereafter. Collections of digesta were made from each of the other sheep before the experiments described here, but these were of less than $8 \mathrm{~h}$ duration.

Total manual collections of duodenal digesta were made as follows. Flexible tubing (Visking Dialysis tubing) was attached to each cannula. Digesta leaving the cannula drained into a polythene measuring cylinder fixed level with the floor of the metabolism crate, and each roo $\mathrm{ml}$ collected was sampled $(5 \%)$ after vigorous manual agitation. The sample was replaced with donor digesta collected the week before each collection and stored frozen until the day of collection. Digesta was returned to the sheep via flexible tubing attached to a plastic funnel clamped to the metabolism crate above the sheep.

The sheep could lie or stand without hindrance to themselves or to the collection apparatus.

\section{Experimental programme}

Expt I. Three sheep (H, M and P) were offered each of diets I-9 in a randomized block design experiment. For each treatment with each sheep, three $24 \mathrm{~h}$ duodenal digesta collections were made. On ten occasions when diets 6-9 were being fed two of the $24 \mathrm{~h}$ collections were made consecutively so that digesta flow was measured over a continuous $48 \mathrm{~h}$ period.

Expt 2. Three sheep were used (M, Q and S). Diets 10-12 were offered in a Latinsquare experimental design. Sheep $S$ was withdrawn from the experiment after completing only two of the three experimental periods because it refused the diet offered. For each treatment with each sheep, one continuous $72 \mathrm{~h}$ duodenal digesta collection was made.

Expt 3. Three sheep were used (Q, W and K). Diets $\mathrm{I}_{4}-\mathrm{r} 6$ were offered to each sheep in a Latin-square experimental design and one $72 \mathrm{~h}$ duodenal digesta collection was made from each sheep on each treatment. In addition three separate $72 \mathrm{~h}$ collections were made from sheep $\mathrm{Q}$ fed on diet 13 .

Treatment of samples. A $5 \%$ sample of digesta was collected and freeze-dried to determine DM.

Statistical analysis. Analysis of variance was used throughout according to Snedecor \& Cochran (1967). Two missing values were calculated for Expt I, one each for sheep $\mathrm{H}$ and $\mathrm{P}$ who refused diets 2 and 7 respectively. For Expt 2 one missing value was calculated for sheep $\mathbf{S}$ who was withdrawn after receiving two of the three experimental diets.

\section{RESULTS}

\section{Expt $\mathrm{I}$}

Table 2 shows the flow of DM and digesta through the duodenum. DM flow was significantly greater $(P<0.05)$ for diets 1,4 and 7 than for other diets. These diets 
Table 2. Expt I. Daily intake of dry matter (DM) ( $g$ ) and passage of DM ( $g$ ) and digesta $(\mathrm{ml})$ through the duodenum of sheep given experimental diets $\mathrm{I}-\mathrm{9}^{*}$

\begin{tabular}{|c|c|c|c|c|c|c|c|c|c|c|}
\hline Diet $\ldots$ & $I$ & 2 & 3 & 4 & 5 & 6 & 7 & 8 & 9 & SE of mean \\
\hline $\begin{array}{l}\text { Intake ... } \\
\text { Duodenal flow }\end{array}$ & I610 & 1050 & 1040 & $I_{320}$ & 1120 & 920 & 1160 & I I 70 & 1040 & - \\
\hline $\begin{array}{l}\text { DM } \\
\text { Digesta }\end{array}$ & $\begin{array}{r}904 \\
16017\end{array}$ & $\begin{array}{r}413 \\
7654\end{array}$ & $\begin{array}{r}363 \\
8696\end{array}$ & $\begin{array}{r}942 \\
18132\end{array}$ & $\begin{array}{r}459 \\
8856\end{array}$ & $\begin{array}{r}396 \\
8618\end{array}$ & $\begin{array}{r}714 \\
13680\end{array}$ & $\begin{array}{r}461 \\
9435\end{array}$ & $\begin{array}{r}452 \\
10496\end{array}$ & $\begin{array}{r}76 \cdot 1 \\
1259 \cdot 0\end{array}$ \\
\hline
\end{tabular}

Table 3. Expt I. Duodenal dry matter (DM) flow in hours 0-24 of a 48 collection represented as a percentage of $\mathrm{DM}$ flow in hours $24-48$ for sheep given diets 6-9*

$\begin{array}{llcrcc}\text { Diet } \ldots & & 6 & 7 & 8 & 9 \\ \text { Sheep } & \text { H } & \text { 107.1 } & 90.4 & 108.8 & 102.8 \\ & \text { M } & - & 101.6 & 118.5 & 111.3 \\ & \text { P } & 107.6 & 55.6 & 119.3 & -\end{array}$

Mean adjusted for missing values $=\mathrm{ro}_{3} \cdot 2 \mathrm{SE}=8 \cdot 94$.

* For details of diets, see Table $\mathbf{I}$.

Table 4. Dry matter (DM) flow through the duodenum of sheep given diets 10-12 (Expt 2) and 14-1 $^{6}$ (Expt 3). Results are presented as mean DM flow $(g)$ in each $24 h$ period of the $72 h$ collection and as daily $\mathrm{DM}$ flow represented as a percentage of mean $\mathrm{DM}$ flow estimated over the entire 72 collection period

\begin{tabular}{|c|c|c|c|c|}
\hline Hours of collection ... & $0-24$ & $24-48$ & $48-72$ & $\mathrm{SE}$ of mean \\
\hline \multicolumn{5}{|l|}{$\begin{array}{l}\text { Mean DM flow through } \\
\text { the duodenum }(g / 24 h)\end{array}$} \\
\hline Expt 2 & 504 & 493 & 473 & $28 \cdot 8$ \\
\hline Expt 3 & 518 & 539 & 550 & $33 \cdot 0$ \\
\hline \multicolumn{5}{|c|}{$\begin{array}{l}\text { Daily DM flow through } \\
\text { the duodenum as a percentage } \\
\text { of mean flow measured over } \\
72 \mathrm{~h}\end{array}$} \\
\hline Expt 2 & 100.4 & $102 \cdot 6$ & $96 \cdot 9$ & $5 \cdot 82$ \\
\hline Expt 3 & 95.8 & Ior 2 & 103.0 & 6.70 \\
\hline
\end{tabular}

contained a large proportion of barley straw. Digesta flow followed a similar pattern, with flow for diets I, 4 and 7 greater $(P<0.05)$ than for all others, with the exception that the difference between diets 7 and 9 was non-significant at the $5 \%$ level.

Coefficients of variation (CV) associated with DM flow and digesta flow were $22 \cdot \mathrm{I}$ and $18.3 \%$ respectively.

When flow was measured continuously over $48 \mathrm{~h}$ the results shown in Table 3 were produced. In this table, flow of DM during the first $24 \mathrm{~h}$ of the $48 \mathrm{~h}$ collection is represented as a percentage of flow during the second $24 \mathrm{~h}$. These results were subjected to analysis of variance for a randomized block experiment with two missing values. Mean DM flow during the first $24 \mathrm{~h}$ of collection was $103.2 \%$ (SE $=8.94$ ) of DM flow during the subsequent $24 \mathrm{~h}$. There were no significant differences between sheep or between diets. 


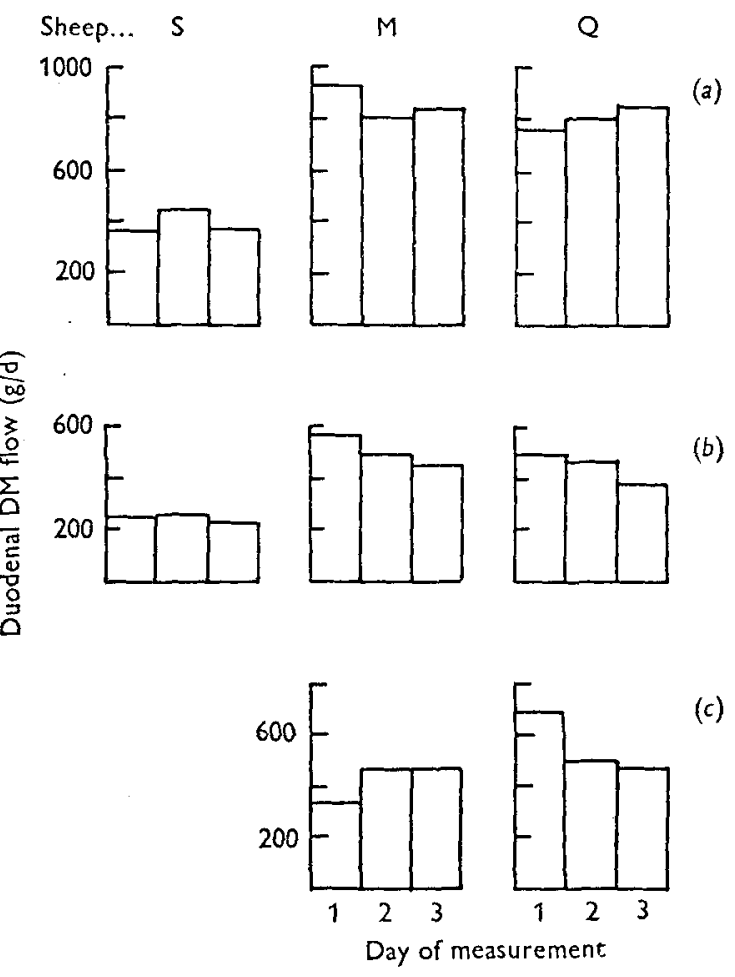

Fig. I. The flow of dry matter (DM), measured on three consecutive days in digesta passing through the duodenum of sheep S, M and Q given (a) diet IO, $(b)$ diet II and (c) diet I 2 (Expt 2). For details of diets, see Table 1 .

\section{Expts 2 and 3}

Duodenal DM flow for diets 10, II and I2 (Expt 2) was 686, 403 and 38I g/24 h (SE of mean $=10.5 \mathrm{~g}$ ) respectively. DM flow for diet 10 was significantly greater $(P<0.05)$ than for diets II and I2. Duodenal DM flow for diets I4, I5 and I6 (Expt 3 ) was 522,523 and $562 \mathrm{~g} / 24 \mathrm{~h}$ (SE of mean $=68.2 \mathrm{~g}$ ) respectively. Differences in DM flow between these diets were not significant.

The results of each $24 \mathrm{~h}$ period of the $72 \mathrm{~h}$ collections carried out in Expts 2 and 3 are compared in Table 4 . The pattern of DM flow for individual measurements is shown in Figs I (Expt 2) and 2 (Expt 3). There was no significant difference between the collection means for $0-24 \mathrm{~h}, 24-48 \mathrm{~h}$ and $48-72 \mathrm{~h}$ in either experiment. When each period of $24 \mathrm{~h}$ was represented as a percentage of mean daily flow over $72 \mathrm{~h}$ there was, again, no significant difference between days in either experiment. Thus $\mathrm{DM}$ flow measured during the first $24 \mathrm{~h}$ of collection did not differ significantly from mean flow measured over $72 \mathrm{~h}$ in either experiment.

The results of three $72 \mathrm{~h}$ collections of digesta from one sheep (Q) given diet 13 are shown in Fig. 3. Mean DM flow was $331 \mathrm{~g} / \mathrm{d}$ (SE of mean $=40.5 \mathrm{~g}$ ) and did not differ significantly $(P>0.05)$ between replicate $72 \mathrm{~h}$ collections. Flow measured on day I of the collections was not significantly different from flow measured on days 2 or 3 . 


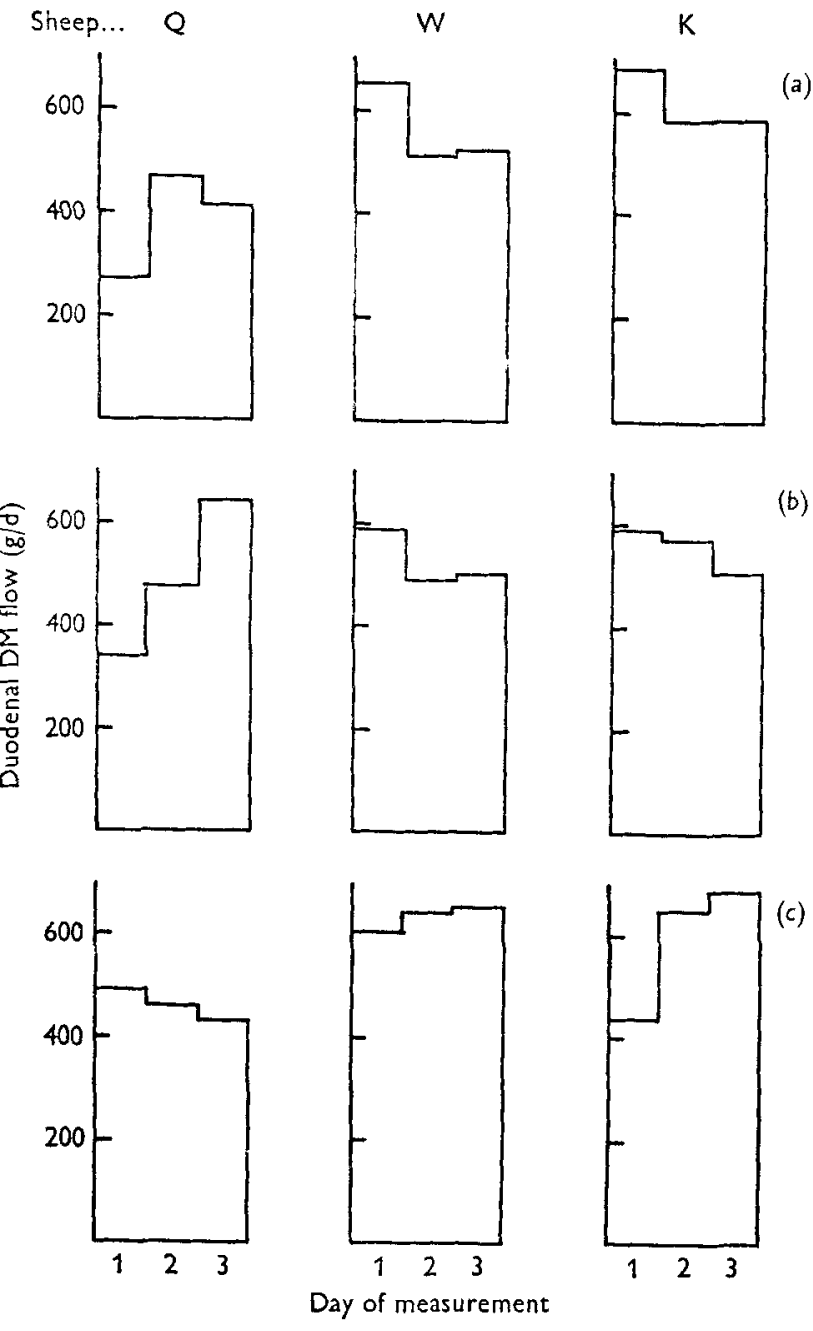

Fig. 2. The flow of dry matter (DM), measured on three consecutive days, in digesta passing through the duodenum of sheep $\mathrm{Q}, \mathrm{W}$ and $\mathrm{K}(a)$ diet $14,(b)$ diet 15 and $(c)$ diet $16(\operatorname{Expt} 3)$. For details of diets, see Table $\mathrm{I}$.

\section{DISCUSSION}

These results have been gathered together from several investigations in which measurements of duodenal digesta flow were made. They contain all of the $72 \mathrm{~h}$ digesta flow measurements made by the authors over a 2 year period, a total of twenty-one collections from sheep fed on a wide variety of diets. In addition there are results from fifty-three $24 \mathrm{~h}$ collections and ten $48 \mathrm{~h}$ collections. These data do not demonstrate any consistent difference in duodenal DM flow between days during $72 \mathrm{~h}$ or $48 \mathrm{~h}$ collections.

There are few reports of digesta collections of longer than $24 \mathrm{~h}$ duration with which to compare these results. All of the available published findings are presented in Table 5. To simplify comparisons, values for $\mathrm{Cr}_{2} \mathrm{O}_{3}$ recovery or DM or digesta 


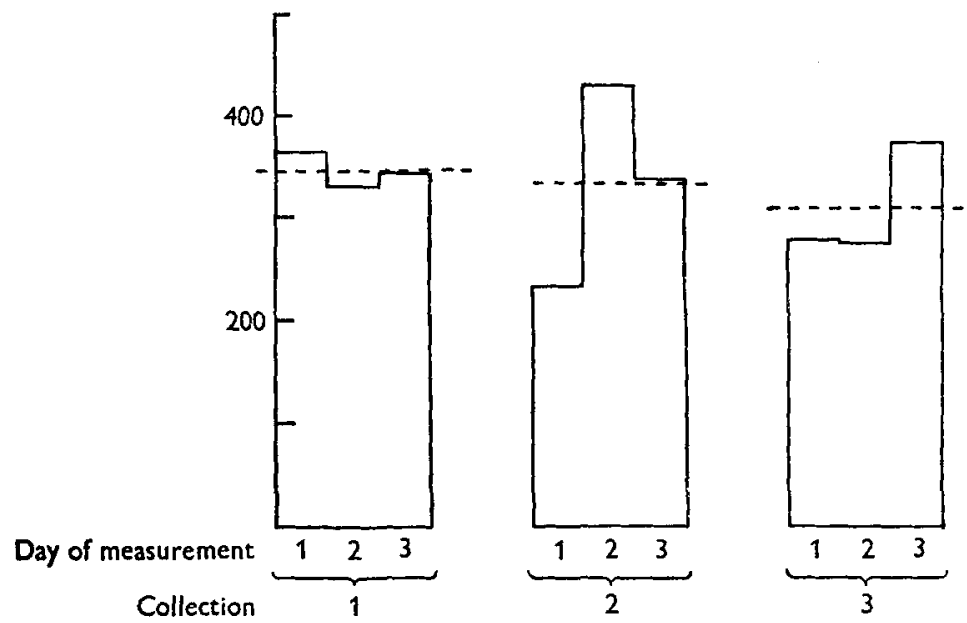

Fig. 3. The flow of dry matter (DM), measured over three consecutive days, on three separate occasions, in digesta passing through the duodenum of one sheep (sheep Q) fed on diet 13 (Expt 3). Dotted lines represent mean DM flow on each occasion. For details of diet, see Table $\mathrm{x}$.

Table 5. A survey of published values for measurements over an extended period of chromic oxide $\left(\mathrm{Cr}_{2} \mathrm{O}_{3}\right)$, dry matter (DM) or whole digesta (digesta) passage in the intestines of ruminants

(Mean values over all animals and treatments represented for each day of collection as a percentage of the mean value for the entire collection)

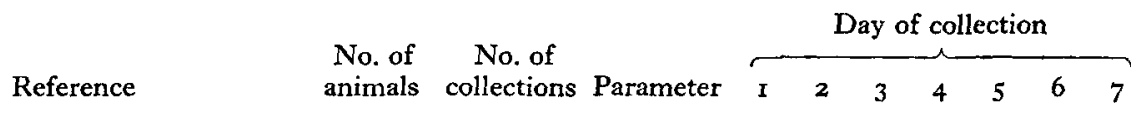

Van 't Klooster, Rogers \& Sharma

\begin{tabular}{|c|c|c|c|c|c|c|c|c|c|c|}
\hline $\begin{array}{l}(1969) \\
\text { Van't Klooster, Kemp, Geurinck \& }\end{array}$ & 2 (sheep) & 2 & $\mathrm{Cr}_{2} \mathrm{O}_{3}$ & 92 & 105 & IOI & & & & \\
\hline Rogers (I972) & 2 (cows) & 4 & $\mathrm{Cr}_{2} \mathrm{O}_{3}$ & $9 \mathrm{I}$ & 99 & 96 & I 12 & 102 & & \\
\hline Osbourn (1975) & (sheep) & 17 & $\mathrm{Cr}_{2} \mathrm{O}_{3}$ & 86 & 94 & 107 & 98 & 103 & 107 & 105 \\
\hline Goodall \& Kay (1965) & 2 (sheep) & 6 & DM & 89 & 104 & 107 & & & & \\
\hline $\begin{array}{l}\text { Thompson \& Lamming (1972) } \\
\text { Johnson \& Armstrong (quoted by }\end{array}$ & 2 (sheep) & 6 & digesta & 99 & 100 & IOI & & & & \\
\hline MacRae, 1975) & I (sheep) & $\mathbf{I}$ & $\mathbf{D M}$ & I00 & 98 & 98 & 106 & 102 & 99 & 98 \\
\hline Sutton, Youssef \& Oldham (1976) & 4 (cows) & 8 & $\begin{array}{c}\mathrm{Cr}_{2} \mathrm{O}_{3} \\
\mathrm{DM} \\
\mathrm{Cr}_{2} \mathrm{O}_{3}\end{array}$ & $\begin{array}{l}99 \\
92 \\
93\end{array}$ & $\begin{array}{r}98 \\
104 \\
100\end{array}$ & $\begin{array}{r}99 \\
103 \\
99\end{array}$ & $\begin{array}{r}107 \\
99 \\
104\end{array}$ & $\begin{array}{r}97 \\
102 \\
104\end{array}$ & 100 & 99 \\
\hline Present results & & & & & & & & & & \\
\hline Expt I (Table 3) & 3 (sheep) & 10 & $\mathbf{D M}$ & 100 & 100 & & & & & \\
\hline Expt 2 (Table 4) & 3 (sheep) & 8 & $\mathbf{D M}$ & 100 & 103 & 97 & & & & \\
\hline Expt 3 (Table 4 ) & 3 (sheep) & 9 & DM & 96 & IOI & 103 & & & & \\
\hline Expt 3 (Figure I) & I (sheep) & 3 & $\mathbf{D M}$ & 89 & 104 & 107 & & & & \\
\hline
\end{tabular}

flow on each day of collection are presented as a percentage of the mean for the whole collection period. The results of van't Klooster et al. (1969, I972) and Osbourn (1975) give support to the concept, first demonstrated by Goodall \& Kay (1965), that digesta flow is depressed during the first $24 \mathrm{~h}$ of collection. However, there is no consistent evidence for a compensatory increase in flow on day 2 of collection from the values in 
Table 5. In $5 \mathrm{~d}$ collections of duodenal digesta from adult cattle with re-entrant cannulas, Sutton et al. (1976) found that $\mathrm{DM}$ flow and $\mathrm{Cr}_{2} \mathrm{O}_{3}$ recovery was lowest on day I of collection, but that correction for $\mathrm{Cr}_{2} \mathrm{O}_{3}$ recovery increased the standard error associated with mean DM flow and only partially reduced day-to-day variation in mean flow. They concluded that it was preferable to avoid adjustment for $\mathrm{Cr}_{2} \mathrm{O}_{3}$ recovery and that $72 \mathrm{~h}$ collections, uncorrected for $\mathrm{Cr}_{2} \mathrm{O}_{3}$ recovery, could be used to measure DM flow at the duodenum. From Table 5 it appears that on those occasions when a reduction in flow was observed on day $\mathrm{I}$ of an extended term measurement, the loss was about $10 \%$.

No significant differences between days of collection were found in Expt 3 when three separate collections of $72 \mathrm{~h}$ duration were made from one sheep, but the mean results (Table 5) for this sheep show a $10 \%$ reduction in DM flow on day $\mathrm{r}$. This was largely the result of a big depression in flow on day i of collection 2 , followed by an elevation in flow on day 2 (Fig. 3). The pattern of flow in collection 2 thus typified the scheme of depression (day I) and compensatory elevation (day 2), suggested by Goodall \& Kay ( 1965 ) but this was not found in collections I and 3, and it appeared to be a chance occurrence. This pattern was rarely seen in the other $72 \mathrm{~h}$ collections (Figs 1 and 2).

No difference in DM flow between day I and subsequent days of collection was found in Expt I, 2 or 3 in agreement with the findings of Thompson \& Lamming (1972). Nevertheless there is the possibility that in this and in the work of Thompson \& Lamming (1972), flow was uniformly depressed throughout the entire $72 \mathrm{~h}$ period. This is unlikely in the light of the other reports cited in Table 5. Recovery of $\mathrm{Cr}_{2} \mathrm{O}_{3}$ over $7 \mathrm{~d}$ was only $93.3 \%$ in Osbourn's (1975) experiments, but recovery increased daily during the first $3 \mathrm{~d}$ of collection. Recovery on day 4 was surprisingly low. In eight duodenal digesta collections from cattle, D. A. Corse (unpublished results) found mean recoveries of $\mathrm{Cr}_{2} \mathrm{O}_{3}$ on days $\mathrm{I}, 2$ and 3 to be 79,90 and $92 \%$ respectively. Represented in the terms of Table 5, recoveries on days 1,2 and 3 were 90, I03 and $106 \%$ respectively. Thus, in relation to the entire collection, $\mathrm{Cr}_{2} \mathrm{O}_{3}$ recovery on day I was reduced by $10 \%$, in agreement with the other reports of a reduction in flow. Though $\mathrm{Cr}_{2} \mathrm{O}_{3}$ recovery was depressed throughout the $72 \mathrm{~h}$ period, the depression on day I was greater than it was on other days. There is, therefore, no supporting evidence for a uniform depression in flow over $72 \mathrm{~h}$ from any of these studies. So it can be concluded that digesta flow was not reduced during the first $24 \mathrm{~h}$ of duodenal digesta collection from our sheep.

This is quite different from the conclusion which must be drawn from those studies in which mean $\mathrm{Cr}_{2} \mathrm{O}_{3}$ recovery in $24 \mathrm{~h}$ duodenal digesta collections has been found to be in the range $82-87 \cdot 1 \%$ (Topps et al. 1968; Bruce et al. 1966; MacRae \& Armstrong, 1969; MacRae et al. 1972; Nicholson \& Sutton, 1969). The approximate $15 \%$ depression in $\mathrm{Cr}_{2} \mathrm{O}_{3}$ recovery found by these workers is similar to the $10 \%$ depression apparent from some sources in Table 5 and, taken together, these various reports strongly suggest that a reduction in digesta flow during the first $24 \mathrm{~h}$ of collection does often occur.

The reason why a depression in flow was not found in the present work is not clear. 
We feel that our sheep were adequately trained to the experimental procedure. No differences between experimental periods were found in Expts 2 and 3 which might have been expected if adaptation to the sampling procedure was a major factor influencing the sheep's response to experimentation. The collection procedure we used was not markedly different from that described by other workers quoted here. As discussed above there is no reason to believe that DM flow was depressed for $72 \mathrm{~h}$ in these experiments as no other workers have observed such an effect. There was no increase in DM flow from day to day which would be likely if flow was grossly depressed at the start of measurement. We therefore conclude that in these experiments DM flow measured over $24 \mathrm{~h}$, without a marker correction, gave a valid estimate of DM flow through the duodenum.

The CV associated with repeated $24 \mathrm{~h}$ measurements of DM flow in Expt $\mathrm{I}$ was $22.1 \%$. In Expts 2 and $3 \mathrm{CV}$ of DM flow was $3.7 \%$ in both instances. These CVs were surprisingly low, and it appeared that variability in measurements of DM flow was reduced in $72 \mathrm{~h}$ measurements in comparison with three separate $24 \mathrm{~h}$ measurements per sheep (Expt $\mathrm{r})$.

MacRae (1975) has reviewed the variability of $\mathrm{Cr}_{2} \mathrm{O}_{3}$-corrected $24 \mathrm{~h}$ digesta DM flow data and found $\mathrm{CV}$ for duodenal flow varying from $5-20 \%$. Our values, therefore, were high, but not dissimilar to those obtained by $\mathrm{Cr}_{2} \mathrm{O}_{3}$ correction. Sutton et al. (1976) found that correcting DM flow for $100 \%$ recovery of $\mathrm{Cr}_{2} \mathrm{O}_{3}$ was of doubtful value for reducing the variability of measurements. Offer, Axford \& Evans (1972) have administered $\mathrm{Cr}_{2} \mathrm{O}_{3}$ to sheep in several ways and used automated sampling equipment (Axford et al. 1971) to measure recovery over several weeks. The variation in $\mathrm{Cr}_{2} \mathrm{O}_{3}$ recovery which they found was a measure of day-to-day variation in $\mathrm{Cr}_{2} \mathrm{O}_{3}$ flow along the duodenum. A direct comparison between the present work and that of the above group is not possible as they gave values for mean recovery with standard errors and the $\mathrm{CV}$ cannot be calculated. However, it is of interest that the variability they found was substantial $\left(93.7 \pm 9.6 \%\right.$ for $\mathrm{Cr}_{2} \mathrm{O}_{3}$ in diet and $99.3 \pm 10 \cdot 2 \%$ for $\mathrm{Cr}_{2} \mathrm{O}_{3}$ paper administered twice daily). Unless the standard errors derived were from a very small number of replicates, $\mathrm{CV}$ for that work would have been at least as great as CV found here for mean DM flow derived from several measurements on a number of sheep. It is concluded, therefore, that our measurements of duodenal DM flow were reproducible within day-to-day variation. In addition our experiments have demonstrated that duodenal DM flow is not always depressed during the first $24 \mathrm{~h}$ of measurement as other workers have shown. Leibholz \& Hartmann (1972) have suggested that $24 \mathrm{~h}$ flow measurements, uncorrected, yield valid estimates of flow. Their conclusion was based on daily recoveries of the marker polyethylene glycol (PEG) which were consistently close to $100 \%$ at the duodenum. PEG has, however, been shown by Corse \& Sutton (1971) to be less satisfactory than $\mathrm{Cr}_{2} \mathrm{O}_{3}$ as a duodenal digesta marker, so the findings of Leibholz \& Hartmann (1972) should be viewed with some caution.

The source of the difference between these studies and most others cannot be identified. The method of collection used here was similar in all major respects to those employed elsewhere. Also, in common with those of most other workers, our 
sheep were familiarized with the experimental procedure before experimentation began. It is regrettable that it is still necessary to rely on such relatively short collection periods to determine nutrient digestibility in the ruminant forestomachs. It is possible that the apparent contradictions between the results reported here and those from elsewhere will be resolved when long-term digesta collections are made practicable. The duration of collection required may then be found to be similar to that for a normal digestibility trial.

The authors wish to thank Dr R. Mawson and Mr G. Neale for excellent surgical preparations, Mrs J. Simpson and Mr J. B. Soar for invaluable assistance during the digesta collections and Mrs P. Buckingham and Mr D. R. Westgarth for a great deal of statistical advice. J.D.O. acknowledges receipt of a Research Assistantship from the Agricultural Research Council. J.R.L. acknowledges receipt of a Postgraduate Agricultural Studentship from the Ministry of Agriculture, Fisheries \& Food.

\section{REFERENCES}

Agricultural Research Council (1965). Nutrient Requirements of Farm Livestock, No. 3 Ruminants, London: Her Majesty's Stationery Office.

Axford, R. F. E., Evans, R. A. \& Offer, N. W. (197I). Res. vet. Sci. 12, 128.

Bruce, J., Goodall, E. D., Kay, R. N. B., Phillipson, A. T. \& Vowles, L. E. (1966). Proc. R. Soc. B. $\mathbf{1 6 6 , 4 6 .}$

Corse, D. A. (1974). Proc. Nutr. Soc. 33, 141 .

Corse, D. A. \& Sutton, J. D. (197x). Proc. Nutr. Soc. 30, 18A.

Drennan, M. J., Holmes, J. H. G. \& Garrett, W. N. (I970). Br. J. Nutr. 24, 96r.

Faichney, G. J. (1972). F. agric. Sci., Camb. 79, 493.

Goodall, E. D. \& Kay, R. N. B. (1965). F. Physiol., Lond. 176, 12.

Leibholz, J. \& Hartmann, P. E. (1972). Aust. F. agric. Res, 23, 1059.

MacRae, J. C. (1974). Proc. Nutr. Soc. 33, I47.

MacRae, J. C. (1975). In Physiology of Digestion in the Ruminant, p. 26r. [1. W. McDonald and A. C. I. Warner, editors]. Armidale: University of New England.

MacRae, J. C. \& Armstrong, D. G. (1969). Br. F. Nutr. 23, 15.

MacRae, J. C., Ulyatt, M. J., Pearce, P. D. \& Hendtlass, J. (I972). Br. F. Nutr. 27, 39.

Nicholson, J. W. G. \& Sutton, J. D. (1969). Br. F. Nutr. 23, 585.

Offer, N. W., Axford, R. F. E. \& Evans, R. A. (1972). Proc. Nutr. Soc. 3r, 39 A.

Offer, N. W., Evans, R. A. \& Axford, R. F. E. (1972). Proc. Nutr. Soc. 31, 104A.

Osbourn, D. F. (1975). Rep. Grassld Res. Inst. 1974, p. 66.

Snedecor, G. W. \& Cochran, W. G. (1967). Statistical Methods 6th edn. Ames, Iowa: Iowa State University Press.

Sutton, J. D., Youssef, F. G. \& Oldham, J. D. (1976). Proc. Nutr. Soc. 35, 100A.

Tas, M. V., Offer, N. W., Evans, R. A. \& Axford, R. F. E. (1974). Proc. Nutr. Soc. 33, 69 A.

Thompson, F. (1973). Br. F. Nutr. 30, 87.

Thompson, F. \& Lamming, G. E. (1972). Br. J. Nutr. 28, 39 I.

Thomson, D. J., Beever, D. E., Coelho da Silva, J. F. \& Armstrong, D. G. (1972). Br. F. Nutr. 28, 3 I. Topps, J. H., Kay, R. N. B. \& Goodall, E. D. (1968). Br. F. Nutr. 22, 26 r.

Ulyatt, M. J. \& MacRae, J. C. (1974). F. agric. Sci., Camb. 82, 295.

van 't Klooster, A. Th., Kemp, A., Geurinck, J. H. \& Rogers, P. A. M. (1972). Neth. f. agric. Sci, 20, 3 I 4 .

van't Klooster, A. Th., Rogers, P. A. M. \& Sharma, H. R. (1969). Neth. Y. agric. Sci. 17, 60. 